\title{
IDENTIFIKASI KEANEKARAGAMAN LAMUN DAN EKHINODERMATA DALAM UPAYA KONSERVASI
}

\author{
(Identification of Diversity of Seagrass and Echinoderms in Conservation Efforts)
}

\section{Krisandy P. Bengkal ${ }^{*}$, Indri S. Manembu ${ }^{1}$, Calvyn F. A. Sondak ${ }^{1}$, Billy Th. Wagey', Joshian N. W. Schaduw ${ }^{1}$, Lawrence J. L. Lumingas ${ }^{2}$.}

1. Program Studi IImu Kelautan, Fakultas Perikanan dan IImu Kelautan, Universitas Sam Ratulangi, Manado.

2. Program Studi Manajemen Sumberdaya Perairan, Fakultas Perikanan dan IImu Kelautan, Universitas Sam Ratulangi, Manado.

*e-mail : bkrisandy@gmail.com

Seagrass play important role in coastal communities for they are one of the supporting factors of various kinds of flora and fauna, affect the productivity of coastal waters, sediment stabilizers control the clarity and quality of water, and can affect other ecosystems around it. The purpose of this study was to analyze the diversity of seagrass species and identify the diversity of echinoderms found on the coast of Tongkaina Village. The method used in this study is the Seagrass Watch method. Data from the study found five types of seagrass, namely Cymodocea rotundata, Cymodocea serrulata, Thalassia hemprichii, Syringodium isoetifolium and Enhalus acoroides which consisted of two families, Hydroccharitaceae and Potamogentonaceae. Seagrass species that are often found at Station I are Cymodocea rotundata with INP value $=109.10$ and at Station II Syringodium isoetifolium with INP value $=$ 141.80. Enhalus acoroides is a type of seagrass that is rarely found on both observation stations, with an INP value $=3.19$ at Station I and at Station II the value of INP $=52.30$. Three species of echhinoderms were found in the quadratic transect, namely Protoreaster nodosus, Ekhinothrix calamaris and Linckia laevigata. The echinoderms diversity index at Station I with the value $H^{\prime}=0.500$ and at Station II with the value $H^{\prime}=0.410$.

Keywords : Identification, Diversity, Seagrass, Echinoderms

Lamun memegang peran penting di komunitas pesisir karena merupakan salah satu faktor pendukung dari berbagai macam flora dan fauna, mempengaruhi produktivitas perairan pesisir, penstabil sedimen mengontrol kejernihan dan kualitas air, serta dapat mempengaruhi ekosistem lain di sekitarnya. Tujuan dari penelitian ini adalah menganalisis keanekaragaman spesies lamun dan mengidentifikasi keanekaragaman ekhinodermata yang ditemukan di pesisir Kelurahan Tongkaina. Metode yang digunakan dalam penelitian ini yaitu metode Seagrass Watch. Data hasil penelitian, ditemukan lima jenis lamun, yaitu Cymodocea rotundata, Cymodocea serrulata, Thalassia hemprichii, Syringodium isoetifolium dan Enhalus acoroides yang terdiri dari dua famili yaitu Hydroccharitaceae dan Potamogentonaceae. Jenis lamun yang sering ditemui di Stasiun I adalah Cymodocea rotundata dengan nilai INP $=109,10$ dan di Stasiun II Syringodium isoetifolium dengan nilai INP $=141,80$. Enhalus acoroides adalah jenis lamun yang jarang ditemui pada kedua stasiun pengamatan, dengan nilai INP $=3,19$ di Stasiun I dan di Stasiun II nilai INP $=52,30$. Ditemukan tiga spesies ekhinodermata yang terdapat dalam transek kuadrat yaitu Protoreaster nodosus Ekhinothrix calamaris dan Linckia laevigata. Indeks keanekaragaman ekhinodermata di Stasiun I dengan nilai $\mathrm{H}^{\prime}=0,500$ dan di Stasiun II dengan nilai $\mathrm{H}^{\prime}=0,410$.

Kata Kunci : Identifikasi, Keanekaragaman, Lamun, Ekhinodermata 


\section{PENDAHULUAN}

Lamun (Seagrass) atau sering juga disebut ilalang laut adalah tumbuhan berbunga (Angiospermae) yang hidup menyesuaikan diri sepenuhnya di dalam air laut (Boneka, 2013). Semua tumbuhan lamun adalah tumbuhan berbiji tunggal (Monokoti) yang memiliki akar, rimpang (Rhizoma), daun, bunga dan buah seperti halnya tumbuhan darat (Tomlinson, 1974 dalam Azkab, 1999). Pada daerah tropis, ekosistem lamun menempati beberapa habitat pantai tetapi secara khas menempati tempat terdangkal berpasir dan berlumpur serta dekat dengan wilayah pantai. Selain itu, lamun sering dijumpai berasosiasi dengan mangrove dan terumbu karang (Short et al, 2004). Ekosistem lamun memegang peran penting di komunitas pesisir karena merupakan salah satu faktor pendukung dari berbagai macam flora dan fauna, mempengaruhi produktivitas perairan pesisir, penstabil sedimen mengontrol kejernihan dan kualitas air, serta dapat mempengaruhi ekosistem lain di sekitarnya. Oleh karena itu penting untuk menjaga ekosistem ini (Coles dkk, 1993).

Pemerintah telah menetapkan Undang-Undang Republik Indonesia Nomor 5 Tahun 1990 tentang Konservasi Sumberdaya Hayati dan Ekosistemnya (Anonim, 1990). Perencanaan, pelaksanaan dan pengelolaan kawasan konservasi laut membutuhkan seluruh perhatian tidak hanya dalam aspek biologi dan oseanografi yang berpengaruh terhadap kawasan, tetapi juga harus memperhatikan aspek sosial, ekonomi dan kelembagaan yang sangat berpengaruh terhadap dampak keberlangsungan kawasan konservasi laut (Charles \& Wilson, 2009).

Ekhinodermata berasal dari bahasa Yunani yaitu echinos yang berarti duri dan derma yang berarti kulit, serta lebih dikenal dengan hewan berkulit duri (Jasin, 1984). Selanjutnya Katili (2011) menginformasikan bahwa ekhinodermata dibagi ke dalam lima kelas yaitu kelas Asteriodea, kelas Crinoidea, kelas Echinodea, kelas Holothuroidea dan kelas Ophiuroidea.

Ekosistem lamun pada umummnya merupakan habitat bagi berbagai jenis organisme laut yang hidup berasosiasi di dalamnya. Organisme bentik sebagai organisme penyerta yang hidup di dasar perairan mempunyai fungsi tersendiri dalam suatu ekosistem perairan. Kondisi kesehatan ekosistem lamun dapat mempengaruhi keberadaan organisme bentik tersebut. Mengingat fungsi ekologis yang cukup penting dan pengamatan terhadap ekhinodermata di padang lamun serta studi keberadaannya masih belum banyak, maka masih sangat perlu untuk dilakukan penelitian lebih lanjut (Riniatsih dan Munasik, 2017).

Tujuan dari penelitian ini adalah menganalisis keanekaragaman spesies lamun dan mengidentifikasi keanekaragaman ekhinodermata yang ditemukan di pesisir Kelurahan Tongkaina.

\section{METODOLOGI PENELITIAN}

\section{Waktu dan Tempat}

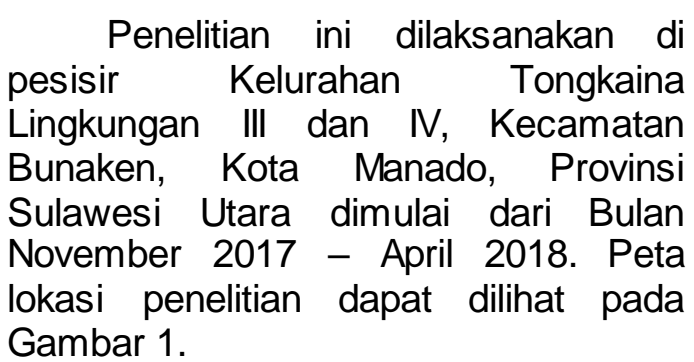

Prosedur Kerja

\section{Metode Seagrass Watch}

Pengamatan terhadap ekosistem lamun dilakukan dengan metode monitoring lamun yang digunakan secara global, yaitu Seagrass Watch Method (McKenzie dan Yoshida, 2009 dalam Taurusman et al, 2013). Adapun cara kerja yang dilakukan pada waktu pengambilan data vegetasi lamun : 


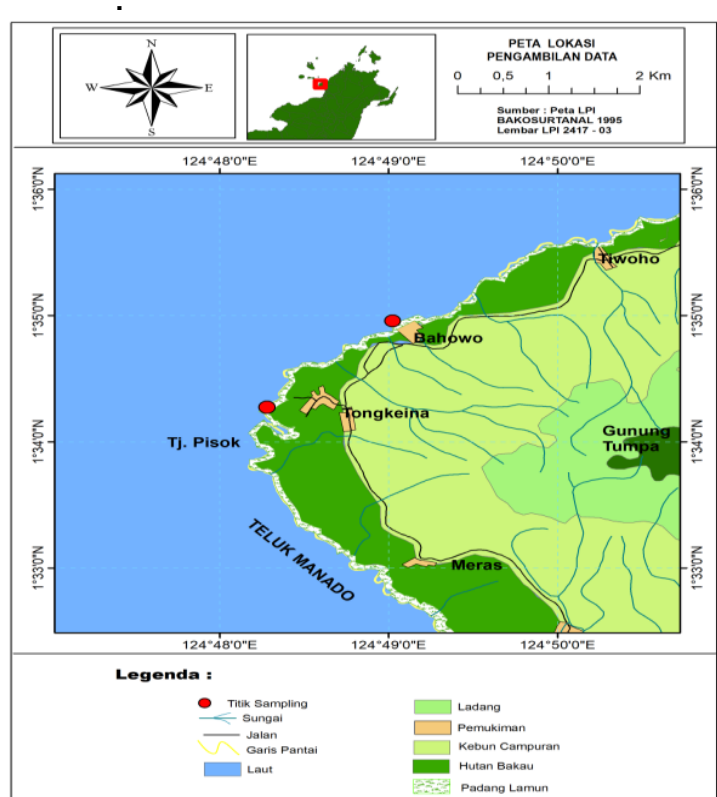

Gambar 1. Peta Lokasi Penelitian

Transek garis sepanjang 50 meter diletakkan dari darat ke arah laut dengan 3 kali ulangan. Jarak antar transek adalah 50 meter; meletakkan kuadrat $\left(50 \times 50 \mathrm{~cm}^{2}\right)$ di sisi kanan garis dengan jarak antar kuadrat 5 meter; Menentukan posisi titik koordinat pada tiap transek garis menggunakan GPSmap 62s (Garmin) ; mengidentifikasi komposisi jenis lamun menggunakan lembar panduan identifikasi yang mengacu pada Rahmawati dkk, 2014; Menggunakan kamera sebagai dokumentasi; Setelah itu, hasil pengamatan persentasi tutupan jenis dan keanekargaman lamun dituliskan pada lembar kerja lapangan yang telah disediakan.

Pengambilan data lamun dan ekhinodermata dilakukan pada transek kuadrat yang sama dengan 3 kali pengulangan. Adapun prosedur kerja yang dilakukan dalam pengambilan data ekhinodermata di lapangan :

Ekhinodermata yang ditemukan dalam transek kuadrat didokumentasikan dengan menggunakan kamera digital, kemudian diidentifikasi berdasarkan klasifikasi Worms World Register of Marine Science (Linnaeus, 1758;
Leske, 1778). Tiap transek garis terdiri dari 10 titik pengambilan data ekhinodermata dengan jarak antar kuadrat 5 meter.

\section{Analisis Data Lamun}

1. Kerapatan Jenis (Di) dihitung dengan rumus (Brower et al, 1998) :

$$
\begin{aligned}
\mathrm{Di}= & \frac{N i}{A} \times 4, \\
\text { di mana }: \mathrm{Di}= & \text { Jumlah individu }-\mathrm{i} \\
& \text { (tegakan) per satuan } \\
& \text { luas }\left(\text { ind } / \mathrm{m}^{2}\right) . \\
\mathrm{Ni}= & \text { Jumlah individu }-\mathrm{i} \\
& \text { (tegakan) dalam } \\
& \text { transek kuadrat. } \\
\mathrm{A}= & \text { Luas transek kuadrat } \\
& \left(\mathrm{m}^{2}\right) .
\end{aligned}
$$

2. Kerapatan relatif (RDi) merupakan perbandingan jumlah spesies dengan jumlah total individu seluruh spesies, dirumuskan :

$$
\begin{aligned}
\mathrm{RDi} & =\frac{N i}{\sum n y}, \\
\text { di mana }: & \mathrm{Rdi}= \\
\mathrm{Ni}= & \text { Kerapatan relatif } \\
& \text { Jumlah individu }-\mathrm{i} \\
& \text { teganan) dalam } \\
\sum \mathrm{ny}= & \text { Jumlah total individu } \\
& \text { seluruh spesies. }
\end{aligned}
$$

3. Frekuensi jenis (Fi) merupakan peluang suatu jenis spesies ditemukan dalam titik contoh yang diamati, dirumuskan :

$$
\mathrm{Fi}=\frac{\mathrm{pi}}{\sum p}
$$

di mana : $\mathrm{Fi}=$ Frekuensi Jenis ke-i.

$$
\begin{aligned}
\mathrm{Pi}= & \text { Jumlah petak contoh } \\
& \text { dimana spesies-i } \\
& \text { ditemukan. } \\
\Sigma \mathrm{p}= & \text { Jumlah total petak } \\
& \text { contoh yang akan } \\
& \text { diamati. }
\end{aligned}
$$

4. Frekuensi Relatif (RFi) adalah perbandingan antara frekuensi spesies-i dan jumlah frekuensi untuk seluruh spesies, dirumuskan :

$$
\mathrm{Rfi}=\frac{f i}{\sum f i},
$$

di mana : $\mathrm{Rfi}=$ Frekuensi Relatif.

$\mathrm{Fi}=$ Frekuensi jenis ke-i.

$\Sigma \mathrm{fi}=$ Jumlah total 
frekuensi seluruh spesies.

5. Penutupan $(\mathrm{Ci})$ adalah luas area yang tertutupi oleh spesies-i, dirumuskan :

$$
\mathrm{Ci}=\frac{\sum(\mathrm{MixFi})}{\sum \mathrm{F}},
$$

(kategori Saito dan Atobe 1970 dalam

English et al., 1994)

di mana : $\mathrm{Ci}=$ Luas area yang tertutupi spesies ke-i.

$\mathrm{fi}=$ Frekuensi (jumlah kotak dengan kelas dominansi yang sama).

$\mathrm{Mi}=$ Titik tengah $\%$ spesies ke-i.

Penentuan persen penutupan lamun (Tabel 1) mengacu pada kelas dominasi yang dikembangkan Saito dan Atobe (1970 dalam English et al. (1994).

6. Penutupan relatif $(\mathrm{RCi})$ adalah perbandingan antara penutupan individu spesies ke-i dengan jumlah total penutupan seluruh jenis :

$$
\mathrm{Rci}=\frac{c i}{\sum c i j},
$$

di mana : Rci = Penutupan relatif.

$$
\begin{aligned}
\mathrm{Ci}= & \text { Luas area yang } \\
& \text { tertutupi jenis ke-i. } \\
\Sigma \mathrm{Cij}= & \begin{array}{l}
\text { Penutupan seluruh } \\
\text { spesies. }
\end{array}
\end{aligned}
$$

7. Indeks nilai penting lamun (INP) digunakan untuk menghitung dan menduga secara keseluruhan dari peranan satu spesies di dalam suatu komunitas. Indeks nilai penting (INP) berkisar antara 0 - 300. INP memberikan gambaran mengenai pengaruh atau peranan suatu jenis tumbuhan terhadap suatu daerah. Semakin tinggi nilai INP suatu spesies relatif terhadap spesies lainnya, maka semakin tinggi peranan spesies tersebut pada komunitasnya. Rumus yang digunakan dalam menghitung INP mengacu pada (Brower et al, 1998), yaitu sebagai berikut :

$$
\begin{aligned}
& \mathbb{N P}=\mathrm{RFI}+\mathrm{RDI}+\mathrm{RCI}, \\
\text { di mana }: & \mathrm{INP}=\text { Indeks nilai penting. } \\
\mathrm{RFi} & =\text { Frekuensi relatif. } \\
\mathrm{RDi} & =\text { Kerapatan relatif. }
\end{aligned}
$$

8. Indeks Keanekaragaman jenis lamun dihitung dengan menggunakan indeks keanekaragaman ShanonWeanner (Brower et al, 1998), yaitu sebagai berikut :

$$
\begin{aligned}
& \mathrm{H}^{\prime}=-\sum \mathrm{Pi} \ln \mathrm{Pi}, \\
& \mathrm{P}=\frac{n i}{N},
\end{aligned}
$$

di mana : $\mathrm{H}^{\prime}=$ Indeks keanekaragaman.

$\mathrm{ni}=$ Jumlah individu jenis ke-i.

$\mathrm{N}=$ Jumlah total individu.

$\mathrm{Pi}=$ Proporsi frekuensi spesies ke-i terhadap jumlah total.

Tabel 1. Kelas dominasi penutupan lamun.

\begin{tabular}{cccc}
\hline Kelas & $\begin{array}{c}\text { Jumlah substrat } \\
\text { yang tertutup }\end{array}$ & $\begin{array}{c}\text { \%penutupan } \\
\text { substrat }\end{array}$ & $\begin{array}{c}\text { Titik } \\
\text { Tengah \% } \\
(\mathrm{M})\end{array}$ \\
\hline 5 & $1 / 2$ hingga semua & $50-100$ & 75 \\
4 & $1 / 4$ hingga 1/2 & $25-50$ & 37,5 \\
3 & $1 / 8$ hingga 1/4 & $12,5-25$ & 18,75 \\
2 & $1 / 16$ hingga 1/8 & $6,25-12,5$ & 9,38 \\
1 & $<1 / 16$ & $<6,25$ & 3,13 \\
0 & Absent & 0 & 0 \\
\hline \multicolumn{4}{c}{ Sumber $:$ Saito dan Atobe (1970) dalam English et al. (1994) }
\end{tabular}




\section{Analisis Data Ekhinodermata}

Organisme bentik (bentos) merupakan organisme yang melekat atau menetap pada dasar atau hidup di dasar endapan. Bentos meliputi organisme nabati (Fitobentos) dan organisme hewani (Zoobentos). Bentos dapat dibagi berdasarkan cara makannya menjadi suspension feeder dan deposit feeder. Bentos di perairan laut ditandai oleh jumlah sessile yang sangat banyak, atau organisme yang secara relatif tidak aktif yang memperagakan ciri zonasi di kawasan pantai (Odum, 1993).

Data jenis ekhinodermata
ditabulasi kemudian dihitung keanekaragamannya dengan menggunakan indeks keanekaragaman menurut "Shannon index of diversity (Odum, 1971).

$$
\mathrm{H}^{\prime}=-\Sigma\left(\frac{n i}{N}\right) \ln \left(\frac{n i}{N}\right)
$$

di mana : $\mathrm{H}^{\prime}=$ Indeks Keanekaragaman

$\mathrm{ni}=$ jumlah individu setiap spesies.

$\mathrm{N}=$ jumlah individu seluruh spesies.

\section{HASIL DAN PEMBAHASAN}

\section{Jenis-jenis Lamun di Pesisir Kelurahan Tongkaina}

Pengamatan yang dilaksanakan di pesisir Kelurahan Tongkaina mengenai keanekaragaman spesies lamun didapatkan lima jenis lamun yang terindentifikasi pada kedua stasiun yaitu : Cymodocea rotundata, Cymodocea serrulata, Thalassia hemprichii, Syringodium isoetifolium dan Enhalus acoroides (Tabel 2). Kelima jenis lamun tersebut termasuk dalam dua famili yaitu Hydroccharitaceae dan Potamogentonaceae. Jenis lamun yang ditemui di Stasiun I yaitu : Cymodocea rotundata, Cymodocea serrulata, Thalassia hemprichii, Syringodium isoetifolium dan Enhalus acoroides. Di Stasiun II hanya ditemukan tiga jenis lamun :
Tabel 2. Jenis-jenis lamun di pesisir Kelurahan Tongkaina

\begin{tabular}{cccc}
\hline \multirow{2}{*}{ No } & \multirow{2}{*}{ Jenis } & \multicolumn{2}{c}{ Stasiun } \\
\cline { 2 - 4 } & & I & II \\
\hline 1 & $C r$ & + & - \\
2 & $C s$ & + & - \\
3 & Th & + & + \\
4 & Si & + & + \\
5 & Ea & + & + \\
\hline
\end{tabular}

Keterangan $:+=$ Ada .

$-=$ Tidak ada .

$\mathrm{Cr}=$ Cymodocea rotundata.

$C s=$ Cymodocea Serrulata.

Th = Thalassia Hemprichii.

$\mathrm{Si}=$ Syringodium isoeffolium.

$E a=$ Enhalus acoroides .

Thalassia hemprichii, Syringodium isoetifolium dan Enhalus acoroides. Hal ini disebabkan karena adanya perbedaan substrat pada kedua lokasi, sehingga jenis lamun yang ditemukan di kedua stasiun pun berbeda.

\section{Struktur Komunitas Lamun di Stasiun I}

Nilai kerapatan jenis Cymodocea rotundata 93,60 (ind $/ \mathrm{m}^{2}$ ), kerapatan relatif 31,69 , frekuensi jenis 0,66 , frekuensi relatif 35,92 , penutupan jenis $23,60 \%$, penutupan relatif 41,49 dan indeks nilai penting 109,10. Nilai kerapatan jenis Cymodocea serrulata 35,60 (ind $/ \mathrm{m}^{2}$ ), kerapatan relatif 13,19 , frekuensi jenis 0,33 , frekuensi relatif 27,67 , penutupan jenis $9,45 \%$, penutupan relatif 16,09 dan indeks nilai penting 56,95. Kerapatan jenis Thalassia hemprichii 64,80 (ind $/ \mathrm{m}^{2}$ ), kerapatan relatif 21,30 , frekuensi jenis 0,37 , frekuensi relatif 19,11 , penutupan jenis $10,21 \%$, penutupan relatif 16,38 dan indeks nilai penting 56,79. Kerapatan jenis Syringodium isoetifolium 102,27 (ind $/ \mathrm{m}^{2}$ ), kerapatan relatif 31,80 , frekuensi jenis 0,52 , frekuensi relatif 25,74 , penutupan jenis $15,71 \%$, penutupan relatif 25,84 dan indeks nilai penting 83,38 . Kerapatan 
jenis Enhalus acoroides 5,87 (ind $/ \mathrm{m}^{2}$ ), nilai kerapatan relatif 2,01 , frekuensi jenis 0,02, frekuensi relatif 0,97 , penutupan jenis $0,11 \%$, penutupan relatif 0,21 dan indeks nilai penting 3,19 . Dengan nilai rata-rata seluruh jenis (Tabel 3) yaitu kerapatan jenis $60,43\left(\mathrm{ind} / \mathrm{m}^{2}\right.$ ), kerapatan relatif 20,00 , frekuensi jenis 0,38 , frekuensi relatif 21,88 , penutupan jenis $11,82 \%$ dan penutupan relatif 20,00 .

\section{Struktur Komunitas Lamun di Stasiun II}

Nilai Kerapatan jenis Thalassia hemprichii 86,80 (ind $/ \mathrm{m}^{2}$ ), kerapatan relatif 34,28, frekuensi jenis 0,60 , frekuensi relatif 36,01 , penutupan jenis $22,12 \%$, penutupan relatif 35,61 dan indeks nilai penting 105,90. Kerapatan jenis Syringodium isoetifolium 126,80 (ind $/ \mathrm{m}^{2}$ ), kerapatan relatif 46,07, frekuensi jenis 0,75 , frekuensi relatif 44,44 , penutupan jenis $31,58 \%$, penutupan relatif 51,29 dan indeks nilai penting 141,80. Kerapatan jenis Enhalus acoroides 35,87 (ind $/ \mathrm{m}^{2}$ ), nilai kerapatan relatif 19,65, frekuensi jenis 0,25 , frekuensi relatif 19,55 , penutupan jenis 5,38\%, penutupan relatif 13,10 dan indeks nilai penting 52,30. Nilai rata-rata seluruh jenis (Tabel 5) yaitu kerapatan jenis 83,16 (ind $\left./ \mathrm{m}^{2}\right)$, kerapatan relatif 33,33 , frekuensi jenis 0,53 , frekuensi relatif 33,33 , penutupan jenis $19,69 \%$ dan penutupan relatif 33,33. Lamun yang mempunyai frekuensi besar umumnya memiliki daya adaptasi yang lebih besar terhadap faktor lingkungan yang berbeda (Ansal et al, 2017).

Berdasarkan hasil penelitian yang telah dilaksanakan, Cymodocea rotundata adalah jenis lamun yang memiliki kemampuan beradaptasi pada beberapa tipe substrat dengan cukup baik sehingga tersebar cukup merata pada stasiun I, akan tetapi jenis lamun ini tidak ditemukan di stasiun II. Berdasarkan Keputusan Menteri Lingkungan Hidup No. 200 Tahun 2004 status tutupan lamun dibagi ke dalam tiga kategori, yaitu tutupan > 60\% dalam kondisi baik (kaya/sehat), 30 -

Tabel 3. Nilai rata-rata struktur komunitas lamun di Stasiun I

\begin{tabular}{|c|c|c|c|c|c|c|c|c|}
\hline No & $\begin{array}{c}\text { Spesie } \\
\mathrm{S}\end{array}$ & $\begin{array}{c}\mathrm{Di} \\
\left.\text { (ind } / \mathrm{m}^{2}\right)\end{array}$ & RDi & $\mathrm{Fi}$ & $\mathrm{RFi}$ & $\begin{array}{c}\mathrm{Ci} \\
(\%)\end{array}$ & Rci & INP \\
\hline 1 & $\mathrm{Cr}$ & 93,60 & 31,69 & 0,66 & 35,92 & 23,60 & 41,49 & $\begin{array}{c}109,1 \\
0\end{array}$ \\
\hline 2 & Cs & 35,60 & 13,19 & 0,33 & 27,67 & 9,45 & 16,09 & 56,95 \\
\hline 3 & Th & 64,80 & 21,30 & 0,37 & 19,11 & 10,21 & 16,38 & 56,79 \\
\hline 4 & Si & 102,27 & 31,80 & 0,52 & 25,74 & 15,71 & 25,84 & 83,38 \\
\hline \multirow[t]{2}{*}{5} & Ea & 5,87 & 2,01 & 0,02 & 0,97 & 0,11 & 0,21 & 3,19 \\
\hline & $\begin{array}{c}\text { Rata- } \\
\text { rata }\end{array}$ & 60,43 & 20,00 & 0,38 & 21,88 & 11,82 & 20,00 & \\
\hline
\end{tabular}

Tabel 4. Nilai rata-rata struktur komunitas lamun di Stasiun II

\begin{tabular}{ccccccccc}
\hline No & Spesies & $\begin{array}{c}\mathrm{Di} \\
\left(\mathrm{ind} / \mathrm{m}^{2}\right)\end{array}$ & $\mathrm{RDi}$ & $\mathrm{Fi}$ & $\mathrm{RFi}$ & $\begin{array}{c}\mathrm{Ci} \\
(\%)\end{array}$ & $\mathrm{Rci}$ & $\mathrm{INP}$ \\
\hline 1 & $\mathrm{Th}$ & 86,80 & 34,28 & 0,60 & 36,01 & 22,12 & 35,61 & $\begin{array}{c}105,9 \\
0\end{array}$ \\
2 & $\mathrm{Si}$ & 126,80 & 46,07 & 0,75 & 44,44 & 31,58 & 51,29 & 141,8 \\
& & 35,87 & 19,65 & 0,25 & 19,55 & 5,38 & 13,10 & 52,30 \\
3 & $\begin{array}{c}\text { Ea } \\
\text { Rata- } \\
\text { rata }\end{array}$ & 83,16 & 33,33 & 0,53 & 33,33 & 19,69 & 33,33 & \\
\hline
\end{tabular}


Tabel 5. Indeks keanekaragaman jenis lamun di pesisir Kelurahan Tongkaina

\begin{tabular}{cc}
\hline \multicolumn{2}{c}{ Indeks Keanekaragaman Jenis Lamun $\left(\mathrm{H}^{\prime}\right)$} \\
\hline Stasiun I & Stasiun II \\
1,388 & 0,990 \\
\hline
\end{tabular}

$59,9 \%$ rusak (kurang kaya/kurang sehat), $<29,9 \%$ miskin..

Penutupan lamun di pesisir Kelurahan Tongkaina tergolong miskin dengan nilai rata-rata pada tiap stasiun, yaitu di Stasiun I memiliki nilai 11,82\% dan di Stasiun II 19,69\%. Hal ini disebabkan karena gangguan dari aktivitas masyarakat lokal di Stasiun I, seperti mencari kerang, memancing ikan dan aktivitas serupa lainnya, serta terdapatnya pelabuhan di Stasiun II yang menyebabkan gangguan bagi ekosistem lamun, seperti tumpahan minyak dari atas kapal, serta gangguan serupa lainnya yang menghambat pertumbuhan dan perkembangan lamun.

Terlihat begitu jelas perbedaan nilai struktur komunitas lamun pada kedua stasiun, di Stasiun I (Tabel 4) indeks nilai penting tertinggi dimiliki oleh Cymodocea rotundata, menunjukkan bahwa jenis lamun tersebut memiliki peran yang besar terhadap komunitasnya dan terendah dimiliki oleh Enhalus acoroides, sedangkan di Stasiun II (Tabel 5) indeks keanekaragaman tertinggi dimiliki oleh Syringodium isoetifolium, dengan demikian jenis lamun tersebut berperan penting terhadap komunitasnya dan indeks keanekaragaman terendah dimiliki oleh Enhalus acoroides. Hal ini disebabkan keberadaan Enhalus acoroides tidak merata pada kuadrat pengamatan di tiap stasiun dibandingkan dengan jenis lainnya. Berbeda dengan penelitian yang dilakukan oleh Menajang $d k k$, (2017) mengenai komunitas lamun di Pulau Bangka menghasilkan nilai uji $t$ kerapatan jenis berbeda (signifikan) yaitu Bangka I 89,6 (ind $/ \mathrm{m}^{2}$ ), Bangka II 68,64 (ind $/ \mathrm{m}^{2}$ ) dan Bangka III 60 (ind $/ \mathrm{m}^{2}$ ), frekuensi jenis Cymodocea rotundata 0,40 (ind $/ \mathrm{m}^{2}$ ), frekuensi relatif 14,68, frekuensi jenis Enhalus acoroides 0,97 (ind $/ \mathrm{m}^{2}$ ), frekuensi relatif 36,74 dan penutupan lamun tertinggi dimiliki oleh Enhalus acoroides sehingga jenis ini yang paling menonjol. Perbedaan kerapatan jenis, frekuensi dan penutupan serta indeks nilai penting lamun di antara kedua lokasi yaitu Kelurahan Tongkaina dan pulau Bangka diduga disebabkan karena adanya pererdaan kondisi lingkungan pada tiap lokasi.

\section{Indeks keanekaragaman jenis lamun}

Berdasarkan Tabel 5, indeks keanekaragaman jenis lamun tertinggi ditemukan di Stasiun I dengan nilai $\mathrm{H}^{\prime}=$ 1,388 dan terendah di Stasiun II dengan nilai $\mathrm{H}^{\prime}=0,990$. Hal ini dikarenakan jenis lamun yang ditemukan di Stasiun I beragam serta terdiri dari lima jenis lamun yang berebeda. Sedangkan di Stasiun II ditemukan hanya tiga jenis lamun yang berbeda.

\section{Identifikasi ekhinodermata di pesisir Kelurahan Tongkaina}

Berdasarkan pengamatan yang telah dilaksanakan pada kedua stasiun, ditemukan tiga spesies ekhinodermata yang terdapat dalam transek kuadrat (Tabel 7), yaitu Protoreaster nodosus (Linnaeus, 1758) sebanyak 4 individu di Stasiun I dan 6 individu di Stasiun II, Ekhinothrix calamaris (Pallas, 1774) 1 individu di Stasiun I dan Linckia laevigata (Linnaeus, 1758) 1 individu di Stasiun II.

Telah dilakukan penelitian oleh Yusron dan Susetiono (2005) mengenai ekhinodermata dari perairan Tanjung Merah, Selat Lembeh, 
Tabel 6. Ekhinodermata di pesisir Kelurahan Tongkaina Tabel 7. Ekhinodermata di pesisir Kelurahan Tongkaina

\begin{tabular}{llll}
\multirow{2}{*}{ No } & \multicolumn{1}{c}{ Biota } & \multicolumn{2}{c}{ Stasiun } \\
\cline { 3 - 4 } & & I & II \\
\hline $\mathbf{1}$ & Protoreaster nodosus & 4 & 6 \\
$\mathbf{2}$ & Ekhinothrix calamaris & 1 & 0 \\
$\mathbf{3}$ & Linckia laevigata & 0 & 1 \\
& Jumlah Spesies & 2 & 2 \\
& Jumlah Individu & 5 & 7 \\
\hline
\end{tabular}

Sulawesi Utara. Stasiun I memiliki substrat pasir halus dan relatif sama dengan Stasiun II dan Stasiun III, yaitu dimulai dengan zona pasir, diikuti oleh zona pertumbuhan lamun, rumput laut dan terumbu karang. Pada ketiga lokasi tersebut didapatkan tumbuhnya berbagai jenis lamun di antaranya jenis Enhalus acoroides, Cymmodocea rotundata dan Thalassia hemprichii. Dari hasil penelitian yang telah dilakukan, terkumpul sekitar 21 jenis ekhinodermata yang mewakili 5 jenis Holothuroidea, 5 jenis Asteroidea, 4 jenis Ekhinoidea dan 7 jenis Ophiuroidea. Kelompok yang paling tinggi kehadirannya dalam pengamatan ini adalah bintang mengular (Ophiuroidea), dari jenis Ophiocoma schoenleini yang ditemukan melimpah pada lokasi yang banyak ditumbuhi lamun. Selanjutnya Yusron (2010) menambahkan ekhinodermata yang ditemukan di perairan Likupang, Minahasa Utara sebanyak 28 jenis yang mewakili 7 jenis Holothuroidea, 9 jenis Echinoidea, 6 jenis Asteroidea dan 6 jenis Ophiuroidea. Kelompok bulu babi atau Echinoidea merupakan kelompok yang paling menonjol di daerah lamun dengan nilai indeks keanekaragaman $\left(H^{\prime}\right)=1,380$.

$$
\text { Indeks keanekaragaman }
$$

tergantung pada variasi jumlah spesies yang terdapat dalam suatu habitat, serta ditentukan oleh jumlah individu dan jumlah individu dari masing-masing spesies sehingga jumlah individu sangat menentukan indeks keanekaragaman. Apabila individu yang ada pada suatu habitat menyebar secara merata, maka indeks keanekaragaman spesies pada habitat tersebut cenderung akan tinggi pula (Sinyo dan Idris, 2013). Indeks keanekaragaman jenis ekhinodermata $\left(\mathrm{H}^{\prime}\right)$ di Stasiun I dengan nilai $\mathrm{H}^{\prime}=0,500$ dan di Stasiun II dengan nilai $H^{\prime}=0,410$ (Tabel 7). Indeks keanekaragaman ekhinodermata di pesisir Kelurahan Tongkaina memiliki nilai indeks keanekaragaman rendah bila dibandingkan dengan penelitian mengenai ekhinodermata yang telah dilaksanakan di Tanjung Merah, Selat Lembeh, Sulawesi Utara dan di perairan Likupang, Minahasa Utara. Hal ini kemungkinan disebabkan karena adanya gangguan dari aktivitas masyarakat lokal lainnya pada kedua Stasiun pengamatan di pesisir KelurahanTongkaina.

Lamun memberikan perlindungan dan tempat menempel dari berbagai hewan dan tumbuhtumbuhan (Hutomo dan Azkab, 1987). Ekhinodermata merupakan salah satu hewan yang sangat penting dalam ekosistem laut dan bermanfaat sebagai salah satu komponen dalam rantai makanan, pemakan sampah organik dan hewan kecil lainnya, sehingga berperan sebagai pembersih lingkungan laut terutama pantai. Selain itu, ekhinodermata juga dapat dijadikan sebagai parameter/bioindikator kualitas perairan ekosistem laut (Jalaluddin dan Ardeslan, 2017). 
Tabel 7. Indeks keanekaragaman Ekhinodermata

\begin{tabular}{cc}
\hline \multicolumn{2}{c}{ Indeks Keanekaragaman } \\
Ekhinodermata (H') \\
\hline Stasiun I & Stasiun II \\
0,500 & 0,410 \\
\hline
\end{tabular}

Selain ekhinodermata, penyu hijau (Chelonia mydas) dan duyung atau dugong (Dugong-dugong) adalah dua hewan yang bergantung pada tumbuhan lamun. Kebergantungan kedua hewan ini terhadap lamun karena tumbuhan tersebut merupakan sumber makanan penyu hijau dan dugong. Penyu hijau biasanya memakan jenis lamun Cymodocea, Thalassia dan Halophila, sedangkan dugong memakan jenis Posidonia dan Halophila (Aswandi, 2008). Selanjutnya menurut Wagey (2013) lamun berperan sebagai penyanggah kelautan dan indikator biologis yang baik. Hal ini disebabkan tumbuhan lamun memberikan respon yang baik terhadap perubahan antropogenik dan dapat mengetahui variabel perubahan lingkungan. Pemantauan ekosistem lamun juga dapat digunakan sebagai salah satu cara untuk melibatkan masyarakat lokal dalam konservasi laut.

\section{KESIMPULAN}

Dari hasil penelitian yang diperoleh, dapat disimpulkan bahwa:

1. Analisis keanekaragaman spesies lamun pada kedua Stasiun di pesisir Kelurahan Tongkaina terdiri dari lima jenis lamun yaitu : Cymodocea rotundata, Cymodocea serrulata, Thalassia hemprichii, Syringodium isoetifolium dan Enhalus acoroides dari dua famili yaitu Hydroccharitaceae dan Potamogentonaceae, serta substrat yang ditemukan di Stasiun I pasir, lumpur dan di Stasiun II yaitu lumpur. Nilai kerapatan jenis tertinggi di
Stasiun I dimiliki oleh Syringodium isoetifolium 102,27 (ind $/ \mathrm{m}^{2}$ ), kerapatan relatif 31,80 . Nilai frekuensi jenis tertinggi dimiliki oleh Cymodocea rotundata 0,66 , frekuensi relatif 35,92 . Nilai penutupan jenis tertinggi dimiliki oleh Cymodocea rotundata $23,60 \%$, penutupan relatif 41,49. Hasil perhitungan analisis indeks nilai penting di Stasiun I menunjukkan jenis yang memiliki nilai tertinggi Cymodocea rotundata 109,10 dan indeks nilai penting terendah dimiliki oleh Enhalus acoroides dengan nilai 3,19 . Dengan nilai rata-rata seluruh jenis (Tabel 4) yaitu kerapatan jenis 60,43 (ind $/ \mathrm{m}^{2}$ ), kerapatan relatif 20,00 , frekuensi jenis 0,38 , frekuensi relatif 21,88 , penutupan jenis $11,82 \%$ dan penutupan relatif 20,00. Di Stasiun II nilai kerapatan jenis tertinggi dimiliki oleh Syringodium isoetifolium 126,80 (ind $/ \mathrm{m}^{2}$ ), kerapatan relatif 46,07 . Nilai frekuensi jenis tertinggi dimiliki oleh Syringodium isoetifolium 0,75 , frekuensi relatif 44,44 . Nilai penutupan jenis tertinggi dimiliki oleh Syringodium isoetifolium $31,58 \%$, penutupan relatif 51,29 . Indeks nilai penting tertinggi dimiliki oleh Syringodium isoetifolium 141,80 dan indeks nilai penting terendah dimiliki oleh Enhalus acoroides 52,30, serta nilai indeks keanekaragaman jenis lamun di Stasiun I dengan nilai $H^{\prime}=1,388$ dan di Stasiun ॥ yaitu $H^{\prime}=0,990$. Berdasarkan hasil analisis stuktur komunitas lamun pada kedua stasiun, indeks nilai penting dan nilai indeks keanekaragaman pada tiap stasiun di pesisir Kelurahan Tongkaina rendah, serta jenis lamun yang ditemukan berbedabeda.

2. Identifikasi keanekaragaman ekhinodermata yang terdapat dalam transek pengamatan pada 
kedua stasiun di pesisir Kelurahan Tongkaina yaitu : Protoreaster nodosus sebanyak 4 individu di Stasiun I dan 6 individu di Stasiun II; Ekhinothrix calamaris 1 individu di Stasiun I dan Linckia laevigata 1 individu di Stasiun I. Nilai indeks keanekaragaman di Stasiun I yaitu : $H^{\prime}=0,500$ dan indeks keanekaragaman di Stasiun ॥ yaitu $H^{\prime}=0,410$. Dengan demikian nilai indeks keanekaragaman ekhinodermata pada kedua stasiun memiliki kisaran rendah. Hal ini kemungkinan disebabkan karena adanya gangguan yang diduga berasal dari aktivitas masyarakat lokal lainnya pada kedua stasiun pengamatan.

\section{DAFTAR PUSTAKA}

Azkab, M.H. 1999. Pedoman Inventarisasi Lamun. Jurnal Oseana. Volume 24. (1): 16 hal.

Aswandi, I. 2008. Crustacea Sebagai Konsumen di Padang Lamun. J. Oseana. 33 (1): 1 - 9.

Ansal, M.H, Priosambodo, D, Litaay, M .,Salam M.A. 2017. Struktur Komunitas Padang Lamun di Perairan Kepulauan Waisai Kabupaten Raja Ampat Papua Barat. Jurnal IImu Alam dan Lingkungan. 8(15): 29 - 37.

Anonim. 1990. Undang-Undang Nomor 5 Tahun 1990 Tentang Konservasi Sumberdaya Alam Hayati dan Ekosistemnya.

Boneka, F.B. 2013. Pengantar Ekologi Laut. Unsrat Press. ISBN 987 $979-3660-11-0.211$ hal.

Brower, J.E, Zar, J.H., Ende, C.N.V. 1998. Field and Laboratory Method For General Ecology Fourth Edition. McGraw-Hill Publication. Boston, USA. hal 25 -51 .
Coles, R.G, Long, W.J.L, Watson, R.A Derbyshire K.J. 1993. Distribution of Seagrasses and Their Fish and Paneid Prawn Communities, in Cairns Harbour, a Tropical Estuary, Northem Queensland, Australia. Northern Fisheries Centre.

Charles, A., Wilson. L. 2009. Human Dimensions of Marine Protected Areas. ICES Journal of Marine Science. hal 6-15.

English, C, Wilkinson., Baker V. 1994. Survey manual for tropical marine resources. ASEAN-Australia Marine Science Project: Living Coastal Resources. Australian Institute of Marine Science. Townsville. 390 hal.

Hutomo, M., Azkab. M.H, 1987. Peranan Lamun di Lingkungan Laut Dangkal. Jurnal Oseana. 12 (1):13 - 23 .

Jalaluddin., Ardeslan. 2017. Identifikasi dan Klasifikasi Phylum Echinodermata di Perairan Laut Desa Sembilan Kecamatan Simeulue Barat Kabupaten Simeulue. Jurnal Biology Education. 6 (1):81 - 97.

Katili, A.S. 2011. Struktur Komunitas Echinodermata Pada Zona Intertidal di Gorontalo. Jurnal Penelitian dan Pendidikan. Volume 8 (1): $51-61$.

Kroh, A., Mooi, R. 2018. World Echinoidea Database. Echinothrix calamaris (Pallas, 1774). Accessed through: World Register of Marine Species at: http://marinespecies.org/aphia.ph $p ? p=$ taxdetails \& $i d=213377$ diakses pada 21-12-2018.

[MENLH] Keputusan Menteri Negara Lingkungan Hidup. 2004. Kriteria Baku Kerusakan dan Pedoman Penentuan Status Padang Lamun. Keputusan Menteri 
Negara Lingkungan Hidup Nomor 200 tahun 2004.

Menajang, F.S.I, Kaligis, G.J.F., Wagey, B.T. 2017. Komunitas Lamun di Pesisir Pantai Pulau Bangka Bagian Selatan Kabupaten Minahasa Utara (Seagrass Community of The Coastal in Southern of Bangka Island, North Minahasa Regancy, North Sulawesi Province). Jurnal IImiah Platax. 5 (2):121 - 134.

Mah, C.L. 2018. World Asteroidea Database. Protoreaster nodosus (Linnaeus, 1758). Accessed through: World Register of Marine Species at: http://marinespecies.org/aphia.ph $p ? p=$ taxdetails \& $i d=213285$ diakses pada 30-11-2018.

Mah, C.L. 2018. World Asteroidea Database. Linckia laevigata (Linnaeus, 1758). Accessed through: World Register of Marine Species at: http://marinespecies.org/aphia.ph $p ? p=$ taxdetails \&id $=207610$. diakses pada 30-11-2018.

Odum, E.P. 1971. Fundamentals of Ecology. Third Edition. W.B. Sounders Company. Philadelphia, London, Toronto. Toppan Company, Ltd. Tokyo, Japan. 574 hal.

Odum, E.P. 1993. Dasar-Dasar Ekologi. (Terjemahan dari Fundamental of Ecology). Samingan $\mathrm{T}$ dan Srigandono B (penerjemah). Gadjah Mada University Press. Yogyakarta. 546 hal.

Rahmawati, S, Irawan, A, Supriyadi, I.H., Azkab, M.H. 2014. Panduan
Monitoring Padang Lamun. Pusat Penelitian Oseanografi-LIPI. Jl. Pasir Putih No. 1, Ancol Timur, Jakarta, 14430. 21 hal.

Riniatsih, I., Munasik. 2017. Keanekaragaman Megabentos Yang Berasosiasi di Ekosistem Padang Lamun Perairan Wailiti, Maumere Kabupaten Sikka, Nusa Tenggara Timur. Jurnal Kelautan Tropis. Volume 20 (1):55 - 59.

Short, F. T, McKenzie. L. J, Coles, R. G .Gaeckle, J. L. 2004. SeagrassNet Manual For Scientific Monitoring of Seagrass Habitat-Western Pacifik Edition. University of New Hamphishire, USA; QDPI, Northem Fisheries Centre, Australia. pp 71.

Sinyo, Y., Idris, J. 2013. Studi Kepadatan dan Keanekaragaman Jenis Organisme Bentos Pada Daerah Padang Lamun di Perairan Pantai Kelurahan Kastela Kecamatan Pulau Ternate. Jurnal Bioedukasi. II. No. (1). ISSN : 2301-4678.

Wagey, B.T. 2013. Hilamun (Seagrass). Upt percetakan dan penerbitan UNSRAT. Unsrat Press Jalan Kampus, Bahu (95115). Manado. Indonesia. 106 hal.

Yurson, E., Susetiono, 2005. Fauna Ekhinodermata Dari Perairan Tanjung Merah Selat Lembeh Sulawesi Utara. Makara, Sains, Volume 9 (2):60 - 65.

Yusron, E. 2010. Keanekaragaman Jenis Ekhinodermata di Perairan Likupang, Minahasa Utara, Sulawesi Utara. Jurnal IImu Kelautan. Volume 15(2):85. 